УДК 656.222.6

\title{
АНАЛІЗ ВАНТАЖНОЇ ТА КОМЕРЦЙНОЇ РОБОТИ ТЕХНІЧНОЇ СТАНЦІЇ В УМОВАХ РЕФОРМУВАННЯ ГАЛУЗІ
}

Канд. техн. наук Я.В. Запара, магістрант І.С. Безуглий

\section{АНАЛИЗ ГРУЗОВОЙ И КОММЕРЧЕСКОЙ РАБОТЫ ТЕХНИЧЕСКОЙ СТАНЦИИ В УСЛОВИЯХ РЕФОРМИРОВАНИЯ ОТРАСЛИ}

Кандидат техн. наук Я.В. Запара, магистрант И.С. Безуглый

\section{ANALYSIS TRUCKS AND COMMERCIAL WORK STATIONS IN THE DESIGN INDUSTRY REFORM}

Cand. of techn. sciences Y. Zapara, master student I. Bezuglyy

Простій місиевого вагона на станиії є одним із основних елементів обігу вантажного вагона. У статті виконано детальний аналіз часу перебування місцевих вагонів та причин затримок на прикладі станиії Ясинувата Донецької залізниці в сучасних умовах.

Запропоновані основні напрямки зменшення часу перебування місцевих вагонів на станиії та запропоновані шляхи їх вирішення.

Ключові слова: місцевий вагон, сортувальна станція, простій місцевого вагона, очікування операчій, технологічна норма.

Простой местного вагона на станции является одним из основных элементов оборота грузового вагона. В статье произведён детальный анализ времени нахождения местных вагонов и 
причин задержек на примере станции Ясиноватая Донеикой железной дороги в современных условиях.

Намечены основные направления уменьшения времени нахождения местных вагонов на станции и предложены пути их решения.

Ключові слова: местный вагон, сортировочная станция, простой местного вагона, ожидания операций, технологическая норма.

Simple local station wagon is one of the key elements of outstanding freight cars. In recent years there has been a tendency of increase in this indicator, which leads to inefficient use of rolling stock on a railway station. In this paper, a detailed analysis of trucks and commercial work at the Donetsk railway station Yasynuvata to meet modern conditions reform that allowed the possible ways of improvement of technology relevant work station. The basic direction of reducing the time of the local station wagons and proposed solutions. Established that such a simple local causes excess wagon as a ban wagon load of Ukrainian transporno and logistics center abroad, renewal of contracts with the owners of rolling stock is not typical in previous years due to changes that occur in the field of rail freight. Carried shift mechanism involved in service work to perform planning, organization and maintenance of local car traffic. Now bounds painted schedule interactions station Directorate, Railway, State Enterprise Ukrainian transporno and logistics center abroad and management of transport Railways .

Keywords: local car, switchyard, simple local car, waiting transactions technological standards.

Вступ. Основною задачею сортувальних станцій є переробка транзитних вагонопотоків. Слід зауважити, що на цих станціях виконується і значний обсяг місцевої роботи. Так, на станції Ясинувата Донецької залізниці місцева робота перевищує 20 тисяч місцевих вагонів за рік.

Постановка проблеми у загальному вигляді та її зв'язок із важливими науковими та практичними завданнями. Вантажну роботу на сортувальних станціях не можна вважати задовільною, тому що останнім часом спостерігається значне перевищення простою місцевого вагона над плановими та нормативними значеннями. За даними показників станції Ясинувата за 2013 рік невиконання плану простою місцевого вагона становить 10 місяців із 12. Така тенденція негативно впливає на основні показники роботи залізниць, зокрема на обіг вантажного вагона, який у 2013 році склав 7,54 доби, що на 1,39 доби більше, ніж у 2012 році. Отже, вдосконалення вантажної та комерційної роботи на сортувальних станціях в період реформування галузі набуває важливого та актуального значення і потребує детального аналізу.

Аналіз останніх досліджень і публікацій. Питанням вдосконалення вантажної та комерційної роботи на станціях приділено багато уваги. Зокрема, дослідженнями в цій галузі займалися як вітчизняні, так і зарубіжні вчені (В.М. Акулінічев, А.М. Берестовий,
М.I. Данько, А.Т. Дерибас, А.М. Котенко, Д.В. Ломотько, В.К. Мироненко, В.В. Повороженко, А.О. Поляков, А.А. Смехов тощо). Серед останніх робіт слід відмітити напрацювання Я.В. Запари, А.О. Ковальова, Р.Г. Коробйової, С.М. Продащук, С.В. Сушарина та інших [1,2]. У публікаціях вчених недостатньо приділено уваги питанням удосконалення вантажної та комерційної роботи сортувальних та інших станцій в умовах реформування галузі [3].

\section{Визначення мети та задачі} дослідження. Необхідним $є$ вирішення завдання зменшення можливих затримок місцевих вагонів на станції та раціональне використання рухомого складу. У роботі проведено детальний аналіз вантажної та комерційної роботи на базі станції Ясинувата Донецької залізниці з урахуванням сучасних умов реформування галузі, що дасть змогу окреслити можливі шляхи удосконалення технології роботи станції.

Основна частина дослідження. Загальний час перебування місцевих вагонів на сортувальній або вантажній станції включає послідовність тривалості певної кількості технологічних операцій та їх очікування, які виконуються над вагоном згідно 3 регламентуючими документами станції $[4,5]$.

Загальний час простою місцевого вагона на станції включає такі елементи: час, який витрачається на операції з прибуття; час на сортування i підбирання вагонів; час 
очікування подачі до вантажних фронтів; час подачі до вантажних фронтів; час очікування вантажних операцій; час перебування під вантажною операцією; час очікування забирання 3 вантажних фронтів; час, який витрачається на забирання вагонів; час формування поїздів, що будуть відправлені; час очікування відправлення; час на операції 3 відправлення, а також у певних випадках - час на виконання та очікування митних операцій; час та очікування переадресування тощо.

Проведено детальний аналіз простою місцевого вагона на прикладі станції Ясинувата Донецької залізниці за період 2012-2013 року (рис. 1). За цей період виконано оцінку динаміки зміни місцевого вагонопотоку (рис. 2) для виявлення відповідних тенденцій залежності простою місцевого вагона від зміни кількості їх обробки на станції.

Дані, наведені на рис. 1 і 2, вказують на таке:

- у період 3 березня по жовтень 2012 року спостерігається збільшення середньодобового місцевого вагонопотоку 3
138 до 157 вагонів, а простій місцевого вагона зменшився 375 (квітень 2012 року) до 45 годин (у липні 2012 року), що вказує на обернено пропорційну залежність часу перебування вагона на станції від кількості місцевих вагонів, які проходять обробку на станції;

- протилежна тенденція спостерігається у 2013 році так 3 квітня по липень простій місцевого вагона збільшився від 61,74 (квітень) до 98,24 години (липень) при стабільному вагонопотоку близько 150 вагонів за добу;

- тенденція обернено пропорційної залежності простою місцевого вагона від середньодобового місцевого вагонопотоку спостерігається в період з листопада 2012 року по березень 2013 року;

- найвищим простій місцевого вагона був у січні 2013 року (124,17 години);

- 3 січня 2013 року на $20 \%$ (до 70,36 години) збільшився план 3 виконання простою місцевого вагона на станції;

- невиконання плану станції 3 простою місцевого вагона у 2012 та 2013 році склав $83 \%$.

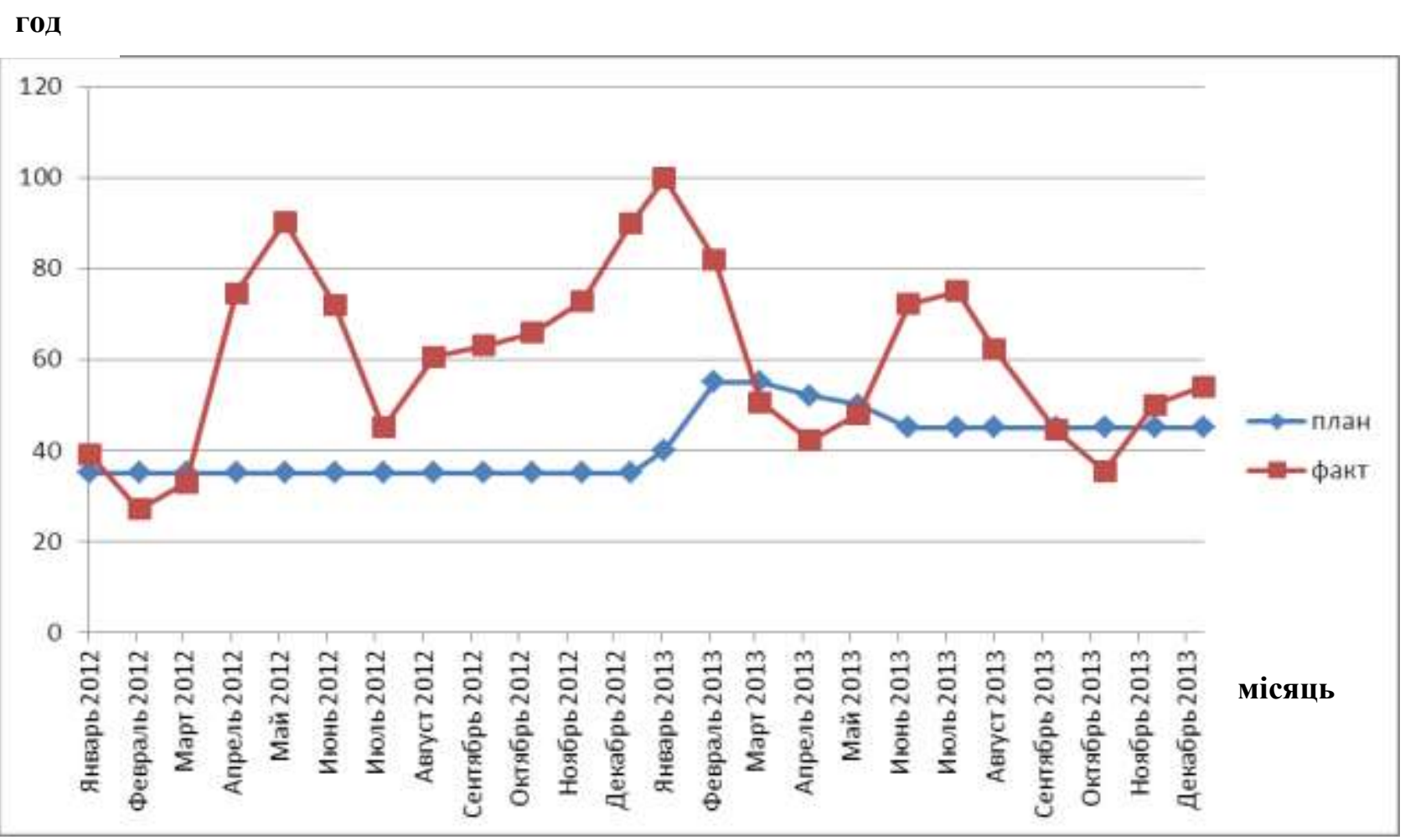

Рис. 1. Простій місцевого вагона під однією вантажною операцією порівняно з планом протягом 2012 та 2013 років по станції Ясинувата Донецької залізниці 




місяць

Рис. 2. Середньодобова кількість оброблених місцевих вагонів протягом 2012 та 2013 років по станції Ясинувата Донецької залізниці

Таким чином, найбільший час перебування місцевого вагона на станції припадає на початок року, що пов'язано із нерівномірним масовим прибуттям місцевих вагонів; залежність простою місцевого вагона від кількості вагонопотоку має різні тенденції, через те, що значення показника простою залежить від багатьох факторів.

Виявлені тенденції спонукають більш детально провести аналіз причин перевищення простою місцевого вагона над плановими та нормативними значеннями та виявлення складових простою, які потребують зменшення.

Основними причинами перевищення часу перебування місцевих вагонів на станції $\epsilon$ : очікування та перебування вагонів під митними операціями (зокрема очікування декларування вагонів 3 відправлення та оформлення митних декларацій на під'їзних коліях), що вказує на недосконалу технологію роботи суміжних структур (у даному випадку залізниці і митниці); очікування переадресування вагонів викликано неузгодженістю відправника, перевізника (залізниці) та отримувача; заборона навантаження вагонів Українського транспорно-логістичного центру (УТЛЦ) за кордон; переукладення договорів з власниками рухомого складу. Інші причини, які мають невеликий відсоток загальних затримок, мають випадковий характер і не мають особливого впливу на зміну простою місцевого вагона.

Останні дві причини є нетиповими для попередніх років i викликані змінами, які відбуваються у галузі вантажних залізничних перевезень. Так, змінився порядок взаємодії Головного управління перевезень, залізниць i ДП «УТЛЦ» в оперативному плануванні i забезпеченні заявок відправників рухомим складом, у якому чітко з'ясовано вертикаль роботи 3 заявками від аналізу достовірності кількості потрібних вагонів до планування i розподілу рухомого складу. Основними перевагами цих змін є більш ефективне і якісне використання вагонів, що полягає в оперативному направленні рухомого складу на підприємства, де відразу він буде навантажуватися. Відповідно планується точна кількість необхідного навантажувального ресурсу до трьох діб включно. У зв'язку з цим, змінився механізм роботи причетних до виконання оперативного плану перевезень усіх служб. Тепер по годинах розписаний графік 
взаємодії станції, дирекції, залізниці, ДП «УТЛЦ» і Головного управління перевезень Укрзалізниці.

Виходячи $з$ тих кроків, які відбуваються у процесі реформування галузі вантажних перевезень, можливо спрогнозувати зменшення простоїв рухомого складу на технічних станціях за рахунок нового порядку взаємодії усіх учасників планування, організації та обслуговування місцевих вагонопотоків.

Висновки 3 дослідження і перспективи, подальший розвиток у даному напрямку. Проведені дослідження дали змогу виявити недоліки у вантажній та комерційній роботі станції Ясинувата Донецької залізниці. Аналіз простою місцевого вагона вказав на необхідність зменшення такої складової, як простій під вантажними операціями та їх очікуванням. Основними причинами перевищення часу перебування місцевих вагонів на станції є: очікування та перебування вагонів під митними операціями; очікування переадресування вагонів та причини пов'язані 3 реформуванням галузі вантажних перевезень, таких як заборона навантаження вагонів УТЛЦ за кордон i переукладення договорів 3 власниками рухомого складу. Виходячи 3 проведеного аналізу, необхідно удосконалити технологію роботи Ясинуватського залізничного вузла в частині розвезення місцевих вагонів; організувати чітку взаємодію залізниці 3 суміжними структурами; ефективніше співпрацювати з відправниками та перевізникам; узгодити взаємодію служб, причетних до планування, організації та обслуговування місцевих вагонопотоків. Запорукою покращення ситуації в роботі 3 місцевими вагонами має стати використання погодинного графіка взаємодії станції, дирекції, залізниці, ДП «УТЛЦ» і Головного управління перевезень Укрзалізниці.

\section{Список використаних джерел}

1. Запара, Я.В. Оцінка часу знаходження місцевого вагонопотоку на станції Основа Південної залізниці [Текст] / Я.В. Запара, В.М. Запара, С.В. Бондарчук // Зб. наук. праць. - Харків: УкрДАЗТ, 2011. - Вип. 120. - С. 5-11.

2. Козаченко, Д.М. Проблеми концентрації роботи з місцевими вагонами залізничних вузлів на технічних станціях [Текст] / Д.М. Козаченко, Р.Г. Коробйова // Проблеми та перспективи розвитку залізничного транспорту: 67 міжнар. наук.-практ. конф., 24-25 травня 2007 р., тези доп. Дніпропетровськ: ДНУЗТ, - 2007. - С. 130-131.

3. Кулешів, В.М. Удосконалення технології сортувальної і вантажної роботи на станціях вузла в умовах розвитку інформатизації [Текст] / В.М. Кулешов, О.О.Сараєв, В.С.Молотов // Зб. наук. праць. - Харків: УкрДАЗТ, 2011.- Вип. 120. - С. 28-34.

4. Ветухов, Е.А. Комплексные методы сокращения простоя вагонов [Текст]/ Е.А. Ветухов, М.А. Аветикян. - М.: Транспорт, 1986. - 206 с.

5. Технологічний процес роботи сортувальної станції Ясинувата [Текст] // Рукопис. - Донецьк: Упр. Донецької залізниці, 2012. - 382 с.

Рецензент д-р техн. наук, професор О.М. Огар

Запара Ярослав Вікторович, канд. техн. наук, доцент кафедри управління вантажною та комерційною роботою Української державної академії залізничного транспорту, тел.: (057) 730-10-85. E-mail: y.zapara@ gmail.com. Безуглий Іван Сергійович, магістрант кафедри управління вантажною та комерційною роботою Української державної академії залізничного транспорту. E-mail: ivan.bezuglyy.85@ mail.ru.

Zapara Yaroslav, cand. of techn. sciences, associate professor of management of freight and commercial work Ukrainian State Academy of Railway Transport, tel.: (057) 730-10-85. E-mail: y.zapara@ gmail.com.

Bezugluyy Ivan, master student of department management of freight and commercial work Ukrainian State Academy of Railway Transport. E-mail: ivan.bezuglyy.85@mail.ru. 